\title{
MEDIA E-LEARNING DENGAN APLIKASI EDMODO DAN SKYPE DALAM PEMBELAJARAN MENULIS PUISI
}

\author{
Rani Rabiussani, Usep Kuswari, Yayat Sudaryat \\ Program Studi Bahasa dan Budaya Sunda, Sekolah Pascasarjana UPI \\ Pos-el: ranirabiussani@gmail.com, usep.kuswari@upi.edu, yayat.sudaryat@upi.edu
}

\begin{abstract}
Abstrak
Penelitian ini dilatarbelakangi oleh pentingnya kedudukan e-learning dalam meningkatkan minat dan kemampuan menulis puisi Sunda siswa kelas XI SMK Negeri 13 Bandung tahun ajaran 2016-2017. Penelitian ini bertujuan untuk mengetahui penerapan media e-learning menggunakan aplikasi Edmodo dan aplikasi Skype dalam meningkatkan kemampuan menulis puisi siswa kelas XI SMK Negeri 13 Bandung. Metode yang digunakan adalah studi eksperimen melalui desain penelitian Alternatif Treatment Post test Only with Non-equivalent Group Design. Sumber data penelitian adalah siswa kelas XI Teknik Komputer Jaringan (TKJ) SMK Negeri 13 Bandung. Instrumen yang digunakan untuk mengumpulkan data adalah instrumen tes, observasi, dan angket. Data yang sudah diperoleh dianalisis menggunakan analisis t-test. Berdasarkan hasil penelitian yang sudah dilaksanakan, rata-rata nilai hasil belajar menulis puisi siswa kelas XI SMK Negeri 13 Bandung yang menggunakan aplikasi Edmodo adalah 76,48 dari Kriteria Ketuntasan Minimal (KKM) 75. Hal tersebut membuktikan bahwa siswa sudah mampu menulis puisi. Sedangkan rata-rata nilai yang menggunakan aplikasi Skype adalah 70,83, yang artinya siswa belum mampu menulis puisi. Setelah dilaksanakan analisis t-test terbukti bahwa tabel dari df (58) dengan kepercayaan 95\%, 2,004, serta jumlah thitung adalah 7,19. Berdasarkan hasil uji hipotesis bisa disimpulkan bahwa $t_{\text {hitung }} \geq t_{\text {tabel }}$, atau $7,19 \geq 2,004$ yang berarti hipotésis alternatif $\left(\mathrm{H}_{1}\right)$ diterima dan hipotesis nol $\left(\mathrm{H}_{0}\right)$ ditolak. Artinya bahwa media e-learning menggunakan aplikasi Edmodo lebih unggul dibandingkan dengan aplikasi Skype dalam meningkatkan kemampuan menulis puisi siswa kelas XI SMKN 13 Bandung tahun ajaran 2016-2017.
\end{abstract}

Kata Kunci: e-learning, aplikasi Edmodo, aplikasi Skype, menulis puisi.

\section{E-LEARNING MEDIA WITH EDMODO AND SKYPE APPLICATION IN WRITING POETRY LEARNING}

\begin{abstract}
This research is motivated by the importance of e-learning in improving the interest and ability to write Sundanese poetry of class XI SMK Negeri 13 Bandung students in 20162017 academic year. This study aims to determine the implementation of e-learning media by using Edmodo and Skype application in improving the writing poetry ability of students of class XI SMK Negeri 13 Bandung. The method used is experimental study through Alternative Treatment Post Test Only with Non-equivalent Group Design research design. The data source is the students of class XI Computer Network Engineering (TKJ) SMK Negeri 13 Bandung. Instruments used to collect the data are test instruments, observations, and questionnaires. The data obtained were analyzed by using t-test. Based on the research results, the average score of students'writing poetry is 76.48 from Minimum Criterion (KKM)
\end{abstract}


75. It proves that students have been able to write poetry. While the average score using the Skype application is 70.83, which means students have not been able to write poetry. After conducted t-test analysis, the results proved that ttable of $d f$ (58) with $95 \%$ degree of confidence, 2.004, and tcount is 7.19. Based on hypothesis, test result can be concluded that tcount $\geq$ ttable, or 7,19 2,004 which mean alternative hypotesis (H1) is accepted and null hypothesis (HO) is rejected. This means that the e-learning media by using Edmodo application is more benefited than the Skype application in improving the writing poetry ability of students of class XI SMKN 13 Bandung in academic year 2016-2017.

Keywords: e-learning, Edmodo app, Skype app, writing poetry.

\section{PENDAHULUAN}

Internet telah berhasil mempersempit ruang dan waktu (timespace compression) serta menghubungkan ribuan bahkan sampai jutaan orang dalam waktu yang sama dengan tempat yang berbeda dan jauh. Dengan internet, jarak dan waktu bisa ditempuh dan dijangkau. Ingin apapun, tinggal klik, semuanya tersedia di mesin pencari seperti Google, Yahoo!, MSN, atau Lycos. Demikian, internet telah menjadi salah satu kemajuan manusia dalam bidang Information and Communication (ICT) atau Teknologi Informasi dan Komunikasi (TIK) abad ke20.

Di era globalisasi kini, internet telah menjadi kebutuhan dalam kehidupan sehari-hari. Secara sederhana, internet merupakan kumpulan jutaan komputer di dunia yang terhubung antara yang satu dengan yang lainnya. Menghubungkan komputer bisa melalui sambungan telepon, kabel, serat optik (fiber optic), satelit, atau tanpa kabel (wireless connection). Waktu komputer dihubungkan dengan internet, segala hal bisa dilakukan, seperti mengirim dan menerima surat, mencari informasi dari artikel atau majalah, komunikasi dan media teks, audio, atau video, serta berbagai hal yang berkaitan dengan aplikasi (lih. Kemdikbud, 2016, hlm. 2-6).

Pada tahun 2017, pemakai internet di Asia berjumlah 1,9 milyar orang. 55,2\% dari jumlah pemakai di seluruh dunia (www.internetworldstats.com/diakses 15
Maret 2017). Adapun di Indonesia, berdasarkan data dari Kementerian Komunikasi jeung Informatika Republik Indonesia, pemakai internet ada 82 juta orang. Dari jumlah tersebut, $80 \%$ merupakan remaja pada rentang usia 15-19 tahun. (https://www.kominfo.go.id/).

Dalam bidang pendidikan, internet dimanfaatkan dalam kegiatan pembelajaran jarak jauh yang disebut e-learning atau distance learning. Menurut Naidu (dalam Suriadhi, Tastra \& Suwatra (2014, hlm. 2), menyebutkan bahwa yang disebut $e$ learning adalah kegiatan disengaja menggunakan TIK dalam kegiatan pembelajaran. Istilah lain yang merujuk pada kegiatan tersebut disebut online learning atau web based learning. Pentingnya internet dalam kegiatan pembelajaran, pada tahun 2006 pemerintah membuat program "Internet Masuk Sekolah" melalui Jejaring Pendidikan Nasional (Jardiknas). Kini, seluruh data sekolah harus diunggah secara online melalui Dapodikdas (SD-SMP) dan Dapodikmen (SMA-SMK). Pada tahun 2007, Kemdikbud memulai program schoolnet, yakni program zona sekolah yang pada tahap awal menghubungkan 6.500 sampai dengan 10.000 sekolah tingkat dasar dan menengah dalam rangka membangun pembelajaran e-learning di seluruh Indonesia (http://sekolah.jardiknas.kemdikbud.go.id, diakses 15 Maret 2017). Bahkan Mendikbud telah mengeluarkan surat 
edaran No. 1 Tahun 2017 yang isinya mewajibkan sekolah-sekolah yang telah memiliki 20 komputer dan 1 server di seluruh Indonesia, untuk melaksanakan CBT (Computer Based Test) atau Ujian Nasional Berbasis Komputer (UNBK).

E-learning merupakan akronim dari electronic learning, artinya pembelajaran yang disampaikan secara elektronik menggunakan media komputer. Materinya diakses melalui jaringan internet, seperti situs web (Smaldino, Lowther \& Russell, 2014, hlm. 235). E-learning merupakan aplikasi internet yang bisa menghubungkan antara guru dengan siswa secara online. Elearning diciptakan untuk mengakali keterbatasan guru dan siswa dalam mengatur waktu, ruang, kondisi dan keadaan (Darmawan, 2014, hlm. 10; Chandrawati, 2010).

Berkaitan dengan e-learning, terdapat istilah kelas maya (Cyber Class; Virtual Class), yakni kelas yang memanfaatkan teknologi internet dengan tujuan agar kegiatan pembelajaran bisa dilaksanakan di mana dan kapan saja. Dalam kegiatan kelas maya, terdapat aplikasi berbasis web, yakni Learning Management System (LMS) dan Learning Content Management System (LCMS). Bahkan kini muncul Social Learning Network (SLN) sebagai alternatif kegiatan pembelajaran, di antaranya yaitu aplikasi Edmodo dan aplikasi Skype. Diimplementasikannya aplikasi Edmodo dan Skype di SMK, diawali oleh Kemdikbud kerjasama dengan Southeast Asian Ministers of Education Organization Regional Open Learning Centre (SEAMEOLEC), yakni Organisasi MenteriMenteri Pendidikan se-Asia Tenggara (http://www.seamolec.org/).

Dengan adanya internet, telah memberikan kesempatan untuk meningkatkan mutu pembelajaran bahasa dan sastra Sunda. Apalagi berbagai program e-learning baik online maupun offline berupa aplikasi untuk pembelajaran bahasa dan sastra Sunda telah banyak, di antaranya aplikasi Edmodo dan Skype.

Aplikasi Edmodo adalah salah satu website pembelajaran gratis dan aman yang dirancang oleh Jeff O'Hara dan Nick Borg pada tahun 2008 untuk guru, siswa, orang tua, dan sekolah yang bisa di-download pada situs www.Edmodo.com. Situs ini bentuknya mirip facebook, tetapi sifatna lebih pribadi (private) dan aman, sebab hanya bisa dipakai oleh guru yang telah membuat account, serta hanya siswa yang sudah memiliki kode grup baru bisa mengakses dan bergabung dengan grup Edmodo. Edmodo adalah platform media sosial seperti facebook yang dihususkan untuk bidang pendidikan (lih. Basori, 2013, hlm.100).

Berbeda dengan aplikasi Edmodo yang interaksinya bersifat tertulis, aplikasi Skype bisa audio-visual. Melalui aplikasi Skype, guru bisa chatting untuk menyampaikan informasi dalam bentuk teks, audio, atau video yang dikenal dengan istilah video conference atau web conference. Hal ini dijelaskan oleh Kemdikbud (2016, hlm. 277), bahwa aplikasi Skype banyak digunakan dalam bidang pendidikan. Hal ini karena aplikasi Skype bisa mengirimkan pesan teks yang didukung oleh fitur video chatting, telephone call, SMS, dan desktop sharing.

Berdasarkan penjelasan di atas, aplikasi Edmodo dan Skype bisa diterapkan pada kegiatan pembelajaran bahasa dan sastra Sunda secara online di SMK. Akan terlihat kekurangan dan keunggulan dari aplikasi keduanya, khususnya yang dapat mendukung meningkatnya mutu pembelajaran menulis puisi.

Banyak penelitian yang membahas e-learning dengan menerapkan aplikasi Edmodo dan aplikasi Skype dalam kegiatan pembelajaran di SMK. Namun hingga kini, penelitian dalam kegiatan pembelajaran bahasa dan sastra Sunda belum dilaksanakan, apalagi dengan membandingkan keunggulan dan 
kekurangan keduanya. Padahal e-learning terasa penting untuk meningkatkan minat, kemampuan, dan motivasi siswa dalam kegiatan menulis puisi Sunda. Apalagi di lingkungan SMK yang membuka jurusan keahlian TKJ, pembelajaran berbasis online sangat didukung. Hal lain bahwa guru-guru telah mendapat pelatihan yang diselenggarakan Kemdikbud kerjasama dengan SEAMO-SEAMOLEC.

Berdasarkan latar belakang di atas, maka masalah dalam penelitian ini dapat dirumuskan sebagai berikut: 1) Bagaimana proses pembelajaran menulis puisi di SMK Negeri 13 Bandung memakai aplikasi Edmodo dan aplikasi Skype? 2) Bagaimana kemampuan menulis puisi siswa di SMK Negeri 13 Bandung memakai aplikasi Edmodo? 3) Bagaimana kemampuan menulis puisi siswa di SMK Negeri 13 Bandung memakai aplikasi Skype? 4) Bagaimana perbandingan kemampuan menulis puisi siswa Kelas XI SMK Negeri 13 Bandung memakai aplikasi Edmodo dan Skype? 5) Bagaimana kualitas proses pembelajaran hubungannya dengan kemampuan menulis puisi siswa Kelas XI SMK Negeri 13 Bandung memakai aplikasi Edmodo dan Skype?

Penelitian ini diharapkan dapat memberikan manfaat antara lain melengkapi teori e-learning dalam pembelajaran bahasa Sunda. Selain itu, diharapkan mampu memperluas cakrawala pengetahuan ihwal diimplementasikannya media berbasis TIK dalam pembelajaran bahasa Sunda.

\section{METODE}

Penelitian ini menggunakan pendekatan kuantitatif. Metode yang dipakai adalah eksperimen dengan desain Alternatif Treatment Post test Only with Non-equivalent Group Design. Menurut Creswell (2017, hlm. 230-231). Pola dari desain ini adalah dengan cara memberikan treatment kepada Kelompok Eksperimen A, lalu peneliti memilih Kelompok B sebagai kelompok perbandingan. Desain ini disebut juga dengan istilah Static Group Comparison Design (Fraenkel \& Wallen, 1993, hlm. 247).

Pada pelaksanaannya, prosedur yang ditempuh sebagai berikut: Kelas A mengikuti pembelajaran menulis puisi menggunakan aplikasi Edmodo, setelah itu diberikan post test. Begitu pula Kelas B, diberikan pembelajaran menulis puisi menggunakan aplikasi Skype, lalu diberikan post test. Hasil keduanya, lalu dibandingkan bagaimana keunggulan dan kelemahan pemakaian aplikasi keduanya. Desain penelitian ini bisa digambarkan pada tabel di bawah ini:

\begin{tabular}{|ll|}
\hline $\mathrm{K}_{4}$ & $\mathrm{X}_{1}$------ $\mathrm{O}_{1}$ \\
$\mathrm{~K}_{\mathrm{B}}$ & $\mathrm{X}_{2}$------ $\mathrm{O}_{2}$ \\
\hline
\end{tabular}

\section{Keterangan:}

KA : Kelompok/Kelas A (Kelas A-Eksperimen)

$\mathrm{KB}$ : Kelompok/Kelas B (Kelas B-Bandingan)

X1 : Perlakuan ke Kelompok/Kelas A

X2 : Perlakuan ke Kelompok/Kelas B

O1 : Post test Kelompok/Kelas A (setelah penerapan aplikasi Edmodo)

O2 : Post test Kelompok/Kelas B (setelah penerapan aplikasi Skype)

(Band. Fraenkel \& Wallen, 1993, hlm. 247; Creswell, 2017, hlm. 231)

Berdasarkan desain penelitian di atas, maka terdapat beberapa prosedur yang ditempuh, antara lain: 1) Menyusun rancangan penelitian yang meliputi: (a) menentukan waktu dan lokasi penelitian, (b) menentukan populasi dan sampel, (c) menyusun instrumen penelitian, dan (d) menentukan hipotesis penelitian, 2) Memilih sekolah dan kelas yang akan dijadikan sampel penelitian, 3) Menyusun media pembelajaran dengan aplikasi Edmodo dan Skype, 4) Mengadakan penelitian dengan menerapkan aplikasi Edmodo dan aplikasi Skype dalam pembelajaran menulis puisi, 5) Mengadakan post test di kelas eksperimen, 6) Menganalisis dan menguji hasil 
eksperimen dengan memakai pedoman statistika yang sesuai, dan 7) Menyusun hasil penelitian dan merumuskan simpulan.

Lokasi penelitian dilaksanakan di SMK Negeri 13 Bandung, di Jl. SoekarnoHatta Km. 10, Bandung 40286, Jawa Barat, Indonesia. SMKN 13 Bandung telah memiliki situs internet yang beralamat di www.smkn-13bdg.sch.id. Membuka tiga kejuruan: Analisis Kimia, Teknik Komputer Jaringan dan Rekayasa Perangkat Lunak.

Penelitian dilaksanakan selama 3 bulan, dari bulan Maret sampai dengan Mei 2017. Populasi penelitian ini adalah siswa Kelas XI SMKN 13 Bandung yang berjumlah 330 orang. Adapun sampel penelitian adalah 30 orang siswa Kelas XI TKJ-1 dan 30 orang siswa XI TKJ-3, sehingga jumlahnya 60 orang.

Pengumpulan data melalui teknik observasi, angket, dan tes. Data yang terkumpul kemudian diolah melalui teknik statistik deskriptif dan inferensial. Teknik mengolah data melingkupi beberapa kegiatan, antara lain: indentifikasi data dan uji sifat data (uji normalitas data, uji homogenitas data, uji hipotesis memakai Uji-t). Instrumen penelitian digunakan sesuai dengan kebutuhan dan kepentingan.

\section{HASIL DAN PEMBAHASAN}

Penelitian ini dilaksanakan di SMK Negeri 13 Bandung selama tiga bulan. Salah satu standar sarana dan prasarana yang diandalkan oleh sekolah ini adalah ketersediaan jaringan internet. Terbukti kegiatan akademik dan non-akademik diselenggarakan secara online. Jaringan internet yang digunakan berupa topologi star, memakai Speedy dan Bizznet dengan kekuatan $50 \mathrm{MB}$, sehingga sinyal tetap stabil.

Berkaitan dengan kegiatan pembelajaran bahasa dan sastra Sunda pada Kurikulum 2013, terdapat Kompetensi Dasar (KD) menulis sajak. Hal ini tercantum pada Peraturan Gubernur Jabar No. 69 Tahun 2013 tentang Pembelajaran
Muatan Lokal Bahasa dan Sastra Daerah pada Jenjang Satuan Pendidikan Dasar dan Menengah, pada bagian lampiran dokumen Kompetensi Inti dan Kompetensi Dasar (KIKD) Mata Pelajaran Bahasa dan Sastra Sunda SMA/SMK/MA/MAK (Disdik Jabar, 2013), bahwa di Kelas XI terdapat Kompetensi Dasar (KD) mengekspresikan sajak sesuai dengan kaidah-kaidahnya baik secara lisan maupun tertulis. Hal ini bermakna bahwa di Kelas XI SMA/SMK/MA/MAK terdapat pembelajaran menulis puisi. Demikian maka perlu upaya peningkatan kemampuan menulis sajak melalui media e-learning dengan aplikasi Edmodo dan aplikasi Skype.

Menurut Endraswara (2003, hlm. 220), menyebutkan bahwa tahapan dalam menulis sajak, yakni: 1) tahap panginderaan, yakni penyair melihat lingkungan yang ada di sekelilingnya. Setelah itu, apapun yang terlihat, terasa, dan terdengar akan dituliskan menjadi sebuah sajak, 2) tahap ngimpleng atau namperkeun gagasan. Biasanya penyair memikirkan apa yang akan dituliskan. Muncul istilah bahwa menulis menunggu ilham atau ilapat. Hal ini merujuk pada tahap ngimpleng dalam rangka namperkeun gagasan terasa penting sekali. Pada tahap ini daya imajinasi dan intuisi penyair diuji. Semakin dalam dan leleb ngimpleng dan berpikir, maka bisa menghasilkan karya yang bernas, 3) tahap ngaruntuykeun kecap. Pada tahap ini, siswa diajak menyusun kata. Hal yang harus diperhatikan adalah estetika, artinya kepiawaian siswa dalam mencari, memilih, dan memilah kata-kata yang disusun untuk menulis sajak.

Ketika penelitian dilaksanakan, mulok pembelajaran bahasa dan sastra Sunda diajarkan mulai Kelas X-XI dengan Kurikulum 2013. Berdasarkan data nilai selama 1 semester, terlihat bahwa nilai Kompetensi Dasar (KD) menulis sajak nilainya paling kecil di antara KD-KD yang lain. 


\section{Grafik Hasil Diajar Pangajaran Basa jeung Sastra Sunda}

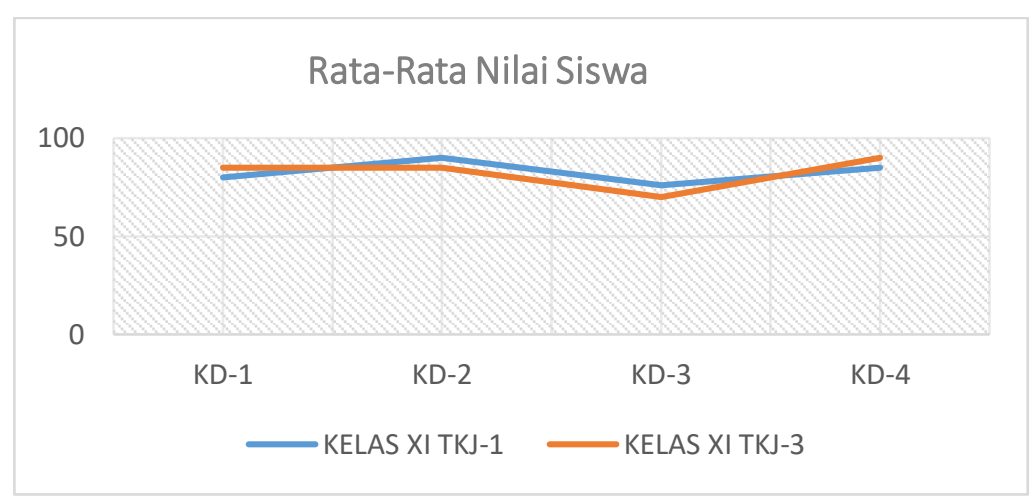

Berdasarkan grafik di atas, terlihat rata-rata nilai tiap KD di Kelas XI TKJ-1 dan XI TKJ-3. Dalam KD-1 (Wawancara), di Kelas XI TKJ-1 rata-rata nilainya 80, begitu pula di Kelas XI TKJ-3 rata-rata nilainya 85. Selanjutnya dalam KD-2 (Pakeman Basa), di Kelas XI TKJ-1 ratarata nilainya 90, dan di Kelas XI TKJ-3 rata-rata 85. Dalam KD-3 (Nulis Sajak), di Kelas XI TKJ-1 rata-rata nilainya 76 , dan di Kelas XI TKJ-3 rata-rata nilainya 70. Terakhir, dalam KD-4 (Pedaran Budaya), di Kelas XI TKJ-1 rata-rata nilainya 85, sedangkan di Kelas XI TKJ-3 rata-rata nilainya mencapai 90.

\section{cmp \& Dayton (dalam Arsyad,} pembelajaran memiliki pengaruh yang baik, antara lain: (1) menyampaikan pembelajaran lebih baku, (2) pembelajaran lebih menyenangkan, (3) Pembelajaran lebih interaktif, (4) Kegiatan pembelajaran lebih singkat, (5) Kualitas pembelajaran bisa lebih meningkat, (6) Kagiatan pembelajaran bisa dilaksanakan di mana dan kapan saja, (7) Sikap serius siswa terhadap hal-hal yang disampaikan dalam kegiatan pembelajaran lebih meningkat, dan (8) Kedudukan guru bisa lebih baik.
Edmodo memudahkan untuk mengontrol interaksi antara guru, siswa, orang tua, dan pihak sekolah (lih. Cahyono, 2015, hlm. 102). Hasil penelitian terhadap Kelas Eksperimen A, diperoleh simpulan bahwa: seluruh siswa hadir dan dapat menggunakan aplikasi Edmodo (100\%) dan siswa aktif serta berhasil menyelesaikan tugas menulis sajak (100\%). Hal ini diawali dengan siswa login ke dalam akun masingmasing menggunakan kode yang sudah dibagikan oleh guru. Selanjutnya siswa mengunduh materi ajar tentang Sajak Sunda, dan mengerjakan tugas yang tertera dalam tampilan Edmodo.

Adapun pembelajaran di Kelas Eksperimen B, diawali dengan sudah tersedianya fasilitas internet yang memadai, selanjutnya dengan menggunakan fitur calling (memanggil) guru menghubungi nomor ketua murid yang sudah ada sebelumnya. Guru menampilkan video bahan ajar sajak kepada siswa. Selanjutnya menugaskan untuk menulis sajak bertema bebas. Sehingga diperoleh simpulan bahwa: seluruh siswa bisa berinteraksi dengan guru melalui video-conference secara aktif. 


\section{Hasil Post Test Menulis Sajak Kelas Ékspérimén A (Edmodo)}

\begin{tabular}{lcccccc}
\hline \multicolumn{1}{|c}{ Kelas } & N & $\begin{array}{c}\text { Total } \\
\text { Skor }\end{array}$ & $\begin{array}{c}\text { Skor } \\
\text { Maks }\end{array}$ & $\begin{array}{c}\text { Skor } \\
\text { Min }\end{array}$ & Mean & $\begin{array}{c}\text { Standar } \\
\text { Deviasi }\end{array}$ \\
\hline $\begin{array}{l}\text { Ékspérimén A } \\
\text { (Edmodo) }\end{array}$ & 30 & 2294 & 92 & 58 & 76,48 & 7,99 \\
\hline
\end{tabular}

Terhadap kegiatan pembelajaran menggunakan aplikasi Edmodo, diperoleh hasil post-test dengan skor maksimal 92 dan skor minimal 58, dengan mean 76,48 dan standar deviasi 7,99. Berdasarkan nilai KKM sebesar 75, maka pembelajaran menulis puisi dengan aplikasi Edmodo ratarata nilainya lebih tinggi dari nilai $\mathrm{KKM}$ yang sudah ditetapkan sebelumnya oleh pihak sekolah.

Berbeda dengan Edmodo, aplikasi Skype guru dan siswa dapat berinteraksi secara langsung melalui tayangan audivisual atau disebut video conference atau web conference_dalam penelitian ini selanjutnya akan disebut vicon (lih. Fitzgibbon, 2003, hlm. 30; Veerraju \& A.
Srinivasa, 2011, hlm. 40; Pandey \& Pande, 2014, hlm. 309).

Menurut Ramadhoni (2014, hlm. 4), aplikasi Skype bisa mendukung kegiatan pembelajaran virtual yang memudahkan guru untuk tidak hadir ke dalam ruangan kelas. Artinya bahwa guru bisa melaksanakan pembelajaran jarak jauh.

Terdapat beberapa langkah yang harus dilaksanakan untuk menggunakan aplikasi Skype, antara lain: a) mengunduh aplikasi Skype, b) menginstal aplikasi Skype, c) membuat akun Skype, d) menggunakan Skype, e) menambah kontak di Skype, dan f) memulai chatting (lih. Kemdikbud, 2016, hlm. 277-287).

\section{Hasil Post Test Menulis Sajak Kelas Ékspérimén B (Skype)}

\begin{tabular}{lcccccc}
\hline \multicolumn{1}{c}{ Kelas } & N & $\begin{array}{c}\text { Total } \\
\text { Skor }\end{array}$ & $\begin{array}{c}\text { Skor } \\
\text { Maks }\end{array}$ & $\begin{array}{c}\text { Skor } \\
\text { Min }\end{array}$ & Mean & $\begin{array}{c}\text { Standar } \\
\text { Deviasi }\end{array}$ \\
\hline $\begin{array}{l}\text { Ékspérimén B } \\
\text { (Skype) }\end{array}$ & 30 & 2125 & 89 & 50 & 70,83 & 10,65 \\
\hline
\end{tabular}

Kemudian atas penggunaan aplikasi Skype, diperoleh hasil post-test dengan skor maksimal 89 dan skor minimal 50, dengan mean 70,83 dan standar deviasi 10,65. Berdasarkan nilai KKM sebesar 75, maka pembelajaran menulis puisi dengan aplikasi Skype rata-rata nilainya lebih rendah dari nilai KKM yang sudah ditetapkan sebelumnya dengan pihak sekolah. Namun berdasarkan data di atas, dapat disimpulkan bahwa pembelajaran menulis puisi menggunakan aplikasi Edmodo rata-rata nilainya lebih baik dari pada menggunakan aplikasi Skype.

Suriadhi (2014) menyebutkan bahwa sebelum melakukan uji hipotesis (uji t) dilakukan uji prasyarat yaitu uji normalitas dan homogenitas. Uji normalitas dilakukan untuk mengetahui apakah sebaran skor pada setiap variabel berdistribusi normal atau tidak, untuk itu dapat digunakan rumus Chi-Kuadrat. Setelah dihitung menggunakan rumus $\mathrm{Chi}$ Kuadrat maka diperoleh hasil perhitungan seperti dibawah ini. 


\section{Hasil Uji Normalitas \\ Data Kelas Ékspérimén A (Edmodo)}

\begin{tabular}{ccccccc}
\hline No. & Data & $\boldsymbol{\alpha}$ & $\mathbf{d k}$ & $\boldsymbol{X}_{\text {hitung }}$ & $\boldsymbol{X}_{\text {tabel }}$ & Keterangan \\
\hline 1. & $\begin{array}{c}\text { Post Test } \\
\text { (Ékspérimén A) }\end{array}$ & 0,05 & 5 & 0,69 & 11,07 & Distribusi data normal \\
\hline
\end{tabular}

Kemudian berdasarkan hasil uji normalitas data Post Test siswa di kelas eksperimen A bahwa nilai $X_{\text {hitung }}$ Post Test kelas A yaitu 0,69. Pada taraf signifikansi
( $\alpha$ ) 0,05 serta $\mathrm{dk}=5$ terlihat nilai $X_{\text {tabel }}=$ 11,07. Oleh karena itu distribusi data di Kelas Eksperimen A normal, sebab $X_{\text {hitung }}<$ $X_{\text {tabel. }}$ atau $X_{0,69}<X_{11,07}$.

Hasil Uji Normalitas

Data Kelas Ékspérimén B (Skype)

\begin{tabular}{ccccccc}
\hline No. & Data & $\boldsymbol{\alpha}$ & $\mathbf{d k}$ & $\boldsymbol{X}_{\text {hitung }}$ & $\boldsymbol{X}_{\text {tabel }}$ & Keterangan \\
\hline 1. & $\begin{array}{c}\text { Post Test } \\
\text { (Ékspérimén B) }\end{array}$ & 0,05 & 5 & 5,01 & 11,07 & Distribusi data normal \\
\hline
\end{tabular}

Adapun hasil uji normalitas data Post Test siswa di kelas eksperimen B bahwa nilai $X_{\text {hitung }}$ Post Test kelas B yaitu 5,01. Pada taraf signifikansi $(\alpha) 0,05$ serta $\mathrm{dk}=5$ terlihat nilai $X_{\text {tabel }}=11,07$. Oleh karena itu, distribusi data di Kelas Eksperimen B normal sebab $X_{\text {hitung }}<X_{\text {tabel }}$. atau $X_{5,01}<X_{11,07}$

\section{Hasil Uji Homogenitas Skor Post Test Kelas Ékspérimén A dan Ékspérimén B}

\begin{tabular}{cccccccc}
\hline No. & Kelas & $\begin{array}{c}\text { Standar } \\
\text { Deviasi }\end{array}$ & $\boldsymbol{\alpha}$ & $\mathbf{d k}$ & $\boldsymbol{F}_{\text {hitung }}$ & $\boldsymbol{F}_{\text {tabel }}$ & Katerangan \\
\hline 1. & Ékspérimén A & 7,99 & 0,05 & 29 & 1,33 & 1,94 & Homogen \\
\hline 2. & Ékspérimén B & 10,65 & 0,05 & 29 & 1,33 & 1,94 & Homogen \\
\hline
\end{tabular}

Kemudian untuk uji homogenitas, dilaksanakan dengan menghitung standar deviasi. Hasil perhitungan dari standar deviasi dipergunakan untuk mencari $F_{\text {hitung. }}$ Ketentuan menetapkan homogenitas data yaitu kalau $F_{\text {hitung }}<F_{\text {tabel }}$ artinya data tersebut homogen, namun kalau $F_{\text {hitung }}>$ $F_{\text {tabel }}$, artinya data tersebut tidak homogen. Hasil hitungan homogenitas data nilai siswa Kelas A dan B adalah sebagai berikut: Nilai $F_{\text {hitung. }}$ kelas eksperimen A, yaitu 1,33, dan $F_{\text {hitung. }}$ kelas eksperimen B yaitu 1,33.
Adapun nilai $F_{\text {tabel }}$ adalah 1,94. Demikian maka data hasil belajar siswa di kelas eksperimen A dan kelas eksperimen B adalah homogen. Oleh karena, seluruh data hasil belajar siswa memiliki nilai $F_{\text {hitung }}<$ $F_{\text {tabel }}$, yaitu $F_{1,33}<F_{1,94}$.

Selanjutnya berkaitan dengan uji hipotesis, diperoleh hasil sebagai berikut. Hipotesis dihitung menggunakan formula $t_{\text {hitung }}$ sampel bebas atau independent samples $t$ test karena data asalnya bukan 
dari kelas yang sama. Ketentuan hasil pengujian sebagai berikut:

- Seandainya $-t_{\text {tabel }} \leq t_{\text {hitung }} \leq t_{\text {tabel }}$, artinya $\mathrm{H}_{0}$ diterima atau $\mathrm{H}_{1}$ ditolak.
- Seandainya $-t_{\text {hitung }} \leq-t_{\text {tabel }}$ atau $t_{\text {hitung }} \geq$ $t_{\text {tabel }}$, artinya $\mathrm{H}_{0}$ ditolak atau $\mathrm{H}_{1}$ diterima.

Uji Bandingan Data Post Test

Kelas Ékspérimén A jeung Ékspérimén B

\begin{tabular}{cccccccc}
\hline \multicolumn{2}{c}{ Mean Post Test } & $\begin{array}{c}\text { Standar } \\
\text { Deviasi }\end{array}$ & $\boldsymbol{\alpha}$ & $\mathbf{d f}$ & $\boldsymbol{T}_{\text {hitung }}$ & $\boldsymbol{T}_{\text {tabel }}$ & Katerangan \\
\cline { 1 - 1 } $\begin{array}{c}\text { Ékspérimén } \\
\text { A }\end{array}$ & $\begin{array}{c}\text { Ékspérimén } \\
\text { B }\end{array}$ & & & & & & \\
\hline $\mathbf{7 6 , 4 8}$ & 70,83 & 3,05 & 0,05 & 58 & 7,19 & 2,004 & $\begin{array}{c}\text { Edmodo lebih } \\
\text { unggul }\end{array}$ \\
\hline
\end{tabular}

Hasil olahan data uji hipotesis dapat dijelaskan bahwa hasil uji $t$, nilai $t_{\text {hitung }}$ 7,19 , dengan menggunakan $\mathrm{df}=\left(n_{1}+\right.$ $\left.n_{2}\right)-2=(30+30)-2=58$ serta taraf signifikansi $5 \%(0,05)$, terlihat nilai $t$ tabel $=$ 2,004. Sebab $t_{\text {hitung }} \geq t_{\text {tabel }}$, atau $7,19 \geq$ 2,004, oleh karena itu $\mathrm{H}_{1}$ diterima serta $\mathrm{H}_{0}$ ditolak. Simpulannya bahwa media $e$ learning menggunakan aplikasi Edmodo lebih unggul dibandingkan dengan aplikasi Skype dalam meningkatkan kemampuan menulis puisi pada siswa Kelas XI SMK Negeri 13 Bandung.

Selanjutnya berdasarkan angket, dari jumlah siswa 30 orang Kelas Eksprerimen A (XI TKJ 1) yang menggunakan aplikasi Edmodo, $73 \%$ menjawab belajar bahasa Sunda menyenangkan, 97\% menjawab menjadi tahu tentang sajak Sunda, dan 93\% belajar menulis sajak menggunakan aplikasi Edmodo merasa lebih gampang dan menyenangkan. Begitu pula sebanyak $87 \%$ siswa menjawab bahwa pembelajaran secara online terasa lebih efektif dan tidak terkekang waktu.

Adapun di Kelas Eksperimen B (XI TKJ 3) yang berjumlah 30 urang, setelah menggunakan aplikasi Skype, 87\% merasa belajar bahasa Sunda menyenangkan, $83 \%$ siswa merasa paham mengenai sajak Sunda, dan $77 \%$ siswa merasa belajar menulis sajak Sunda lebih gampang dan menyenangkan. Begitu pula $80 \%$ siswa merasa bahwa pembelajaran melalui media online terasa lebih efektif dan tidak terkekang waktu.

Menurut Ariani (2016, hlm. 26), siswa dianggap kreatif dalam menulis sajak apabila bisa mengintegrasikan proses dan produk. Hasil dari proses apabila siswa dan guru memiliki keseriusan dalam pembelajaran, sehingga suasana menjadi efektif dan kondusif. Dalam pembelajaran menulis sajak terdapat dua unsur yang menjadi bahan penilaian, yaitu unsur lahir dan unsur batin. Unsur lahir meliputi: 1) diksi (diction) atau pilihan kata, 2) citraan (imagery), 3) Rakitan basa (basa figuratif, majas, atau gaya basa), 4) Purwakanti (rhyme), dan 5) tipografi. Adapun unsur batin, meliputi: jejer (tema; sense), 2) wirahma (nada; tone), 3) wirasa, dan 4) amanat. Lebih jelasnya dapat dilihat pada bagan di bawah ini. 


\section{Bagan Bentuk dan Unsur Sajak Sunda}

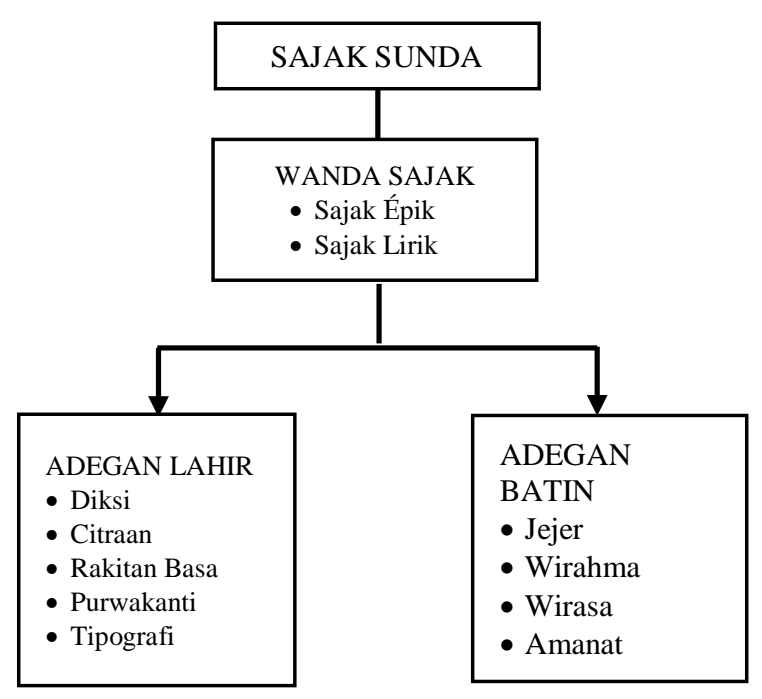

Selanjutnya berkaitan dengan penilaian atas sajak hasil karya siswa, ditemukan adanya peningkatan nilai yang diperoleh siswa dengan gambaran sebagai berikut. Dari jumlah siswa sebanyak 30 orang, 2,9 telah menggunakan diksi yang tepat, 3,1 citraan dalam sajak masih kurang membangun makna, 3,0 memakai gaya bahasa yang tepat, 2,9 menggunakan purwakanti dan 3,3 cukup kreatif dalam menyusun tipografi sajak. Adapun pada aspek unsur batin, diperoleh gambaran sebagai berikut: 3,3 tema sesuai isi sajak, 2,8 kurang adanya variasi wirahma, 2,7 cukup jelas adanya rasa, dan 3,5 amanat telah jelas dan dapat dipahami secara lugas.

Adapun pada Kelas Eksperimen B, dari jumlah siswa sebanyak 30 orang, ratarata kriteria penilaian berada pada skor 2,8 telah menggunakan diksi yang tepat, 2,7 citraan dalam sajak masih kurang membangun makna, 2,7 memakai gaya bahasa yang tepat, 2,7 menggunakan purwakanti dan 2,7 cukup kreatif dalam menyusun tipografi sajak. Adapun pada aspek unsur batin, diperoleh gambaran sebagai berikut: 3,2 tema sesuai isi sajak, 2,7 kurang adanya variasi wirahma, 2,5 cukup jelas adanya rasa, dan 3,3 amanat telah jelas dan dapat dipahami secara lugas.

Dengan demikian, berdasarkan hasil analisis data di atas, dapat disimpulkan bahwa media e-learning menggunakan aplikasi Edmodo lebih unggul daripada aplikasi Skype dalam upaya meningkatkan kemampuan menulis sajak siswa Kelas XI SMK Negeri 13 Bandung.

\section{SIMPULAN}

Berdasarkan hasil penelitian, dapat disimpulkan antara lain:

1. Pembelajaran bahasa dan sastra Sunda di SMK, khususnya yang membuka Jurusan Teknik Komputer Jaringan (TKJ) serta secara umum sekolahnya telah dilengkapi fasilitas jaringan internet, maka dapat diintegrasikan dengan perkembangan Teknologi Komunikasi dan Informasi (TIK);

2. Perkembangan TIK yang kemudian melahirkan konsep e-learning, sejatinya memiliki tujuan untuk meningkatkan mutu atau kualitas pendidikan;

3. Media e-learning menggunakan aplikasi Edmodo dan aplikasi Skype sangat mendukung dalam upaya meningkatkan 
kemampuan menulis siswa Kelas XI SMK Negeri 13 Bandung;

4. Setelah diaplikasikan media pembelajaran berbasis e-learning dengan aplikasi Edmodo dan aplikasi Skype, maka siswa merasa gampang dan senang dalam kegiatan pembelajaran bahasa dan sastra Sunda. Selain itu terbukti berdasarkan hasil uji statistik, bahwa aplikasi Edmodo lebih unggul daripada aplikasi Skype, dan;

5. Terdapat peningkatan dalam kemampuan menulis siswa Kelas XI SMK Negeri 13 Bandung setelah diterapkan kegiatan pembelajaran berbasis TIK.

Selanjutnya berkaitan dengan hasil penelitian tersebut, maka disarankan perlu dilaksanakan penelitian lanjutan ihwal pengintegrasian TIK dengan pembelajaran bahasa dan sastra Sunda. Hal ini dilaksanakan agar ke depan pembelajaran bahasa dan sastra Sunda mendapat posisi yang setara serta sederajat dengan mata pelajaran-mata pelajaran lainnya di sekolah.

\section{PUSTAKA RUJUKAN}

Arsyad, Azhar. 2016. Media pembelajaran. Jakarta: Rajagrafindo.

Ariani, Farida. 2016. Modul guru pembelajar mata pelajaran bahasa indonesia SMA/SMK: menulis puisi dan apresiasi drama. Jakarta: Dirjen GTK.

Basori. 2013. Pemanfaatan social learning network "edmodo" dalam membantu perkuliahan teori bodi otomotif di prodi PTM JPTK FKIP UNS. JIPTEK, 4 (2), Juli 2013

Cahyono, Yulius Dwi. 2015. E-Learning (EDMODO) sebagai Media Pembelajaran Sejarah. Jurnal Penelitian Universitas Sanata Dharma Yogyakarta. 18 (2), hlm. 102-112.

Chandrawati, Sri Rahayu. 2010. Pemanfaatan E-learning dalam
Pembelajaran. 8 http://jurnal.untan.ac.id/

Creswell, John W. 2017. Research design: pendekatan, metode kualitatif, kuantitatif, dan campuran. Yogyakarta: Pustaka Pelajar.

Darmawan, Deni. 2014. Pengembangan elearning teori dan desain. Bandung: Remaja Rosdakarya.

Disdik Provinsi Jawa Barat. 2013. Kurikulum Tingkat Daerah Mata Pelajaran Bahasa dan Sastra Sunda Berbasis Kurikulum 2013. Bandung: Disdik Provinsi Jawa Barat.

Endraswara, Suwardi. (2003). Metodologi penelitian sastra. Yogyakarta: Pustaka Widyatama.

Fitzgibbon, Paula. 2003. Challenges of Video-Conferencing Teaching anda Effective Teaching Methods. The Turkish Online Journal of Educational Technology - TOJET. 2 (3). hlm. 3034.

Fraenkel, Jack R. \& Norman E. Wallen. 1993. How to design and evaluate research in education. Singapore: Monotype Composition Company.

http://sekolah.jardiknas.kemdikbud.go.id (online) (15 Maret 2017)

http://www.internetworldstats.com (online) (15-3-2017)

http://www.kominfo.go.id (online) (10-32017)

http://www.seamolec.org/ (online) ) Maret 2017)

Kemdikbud. (2016). Panduan penggunaan aplikasi video conference cisco webex. Jakarta: Dirjen dikdasmen- Direktorat PSMK.

Pandey, Harsha \& P. P. Pande. 2014. Video conferencing: An Efficient E-Learning Tool for Distance Education. International Journal of Innovation 
and Scientific Research. 10 (2), hlm. 308-311.

Peraturan Gubernur Jabar No. 69 Tentang Pembelajaran Muatan Lokal Bahasa dan Sastra Daerah pada Jenjang Satuan Pendidikan Dasar dan Menengah.

Ramadhoni, Bilton. 2014. Efektivitas penggunaan virtual learning dengan menggunakan aplikasi Skype terhadap hasil belajar siswa pada mata pelajaran teknologi informasi dan komunikasi. (Skripsi). Universitas Pendidikan Indonesia, Bandung.

Smaldino, Sharon E, Deborah L. Lowther, \& James D. Russell. 2014. Instructional technology \& media for learning. Jakarta: Kencana Prenadamedia Group.
Suriadhi, Gede I, I Dewa Kade Tastra, \& Ign. Wayan Suwatra. 2014. Pengembangan E-Learning Berbasis Edmodo Pada Mata Pelajaran IPA Kelas VIII Di SMP Negeri 2 Singaraja. Journal Edutech Universitas Pendidikan Ganesha Jurusan Teknologi Pendidikan. 2 (1), tahun 2014.

Veerraju, R. P. S. P. \& A. Srinivasa Rao. 2011. Benefits of video conferencing. International Journal of Hybrid Computational Intelligence, 4 (1-2), hlm. 39-42.

\section{UCAPAN TERIMA KASIH}

Terimakasih penulis sampaikan kepada semua pihak yang telah membantu penelitian ini, terutama kepada Penyunting Jurnal Lokabasa atas dimuatnya tulisan ini. 